\begin{tabular}{|c|c|}
\hline $\begin{array}{l}\text { 2. To: (Receiving Organization) } \\
\text { DISTRIBUTION }\end{array}$ & $\begin{array}{l}\text { 3. From: (originating Organization) } \\
\text { SNF Storage Projects }\end{array}$ \\
\hline $\begin{array}{l}\text { 5. Proj./Prog./Dept./Div.: } \\
\text { Spent Nuclear Fuel Project }\end{array}$ & $\begin{array}{l}\text { 6. Design Authority/ Design Agent/Cog. } \\
\text { Engr.: } \\
\text { L. Goldmann }\end{array}$ \\
\hline
\end{tabular}

8. Originator Remarks:

For Release

3. From: (originating Organization)

4. Related EDT No.: SNF Storage Projects

$\mathrm{N} / \mathrm{A}$

7. Purchase Order No.:

$\mathrm{N} / \mathrm{A}$

9. Equip./Component No.: $\mathrm{N} / \mathrm{A}$

10. System/Bldg./Facility: $212 \mathrm{H}$

11. Receiver Remarks: 11A. Design Baseline Document? [] Yes [X] No

12. Major Assm. Dwg. No.:

$\mathrm{MCO}$

13. Permit/Permit Application No.: $\mathrm{N} / \mathrm{A}$

14. Required Response Date: N/A

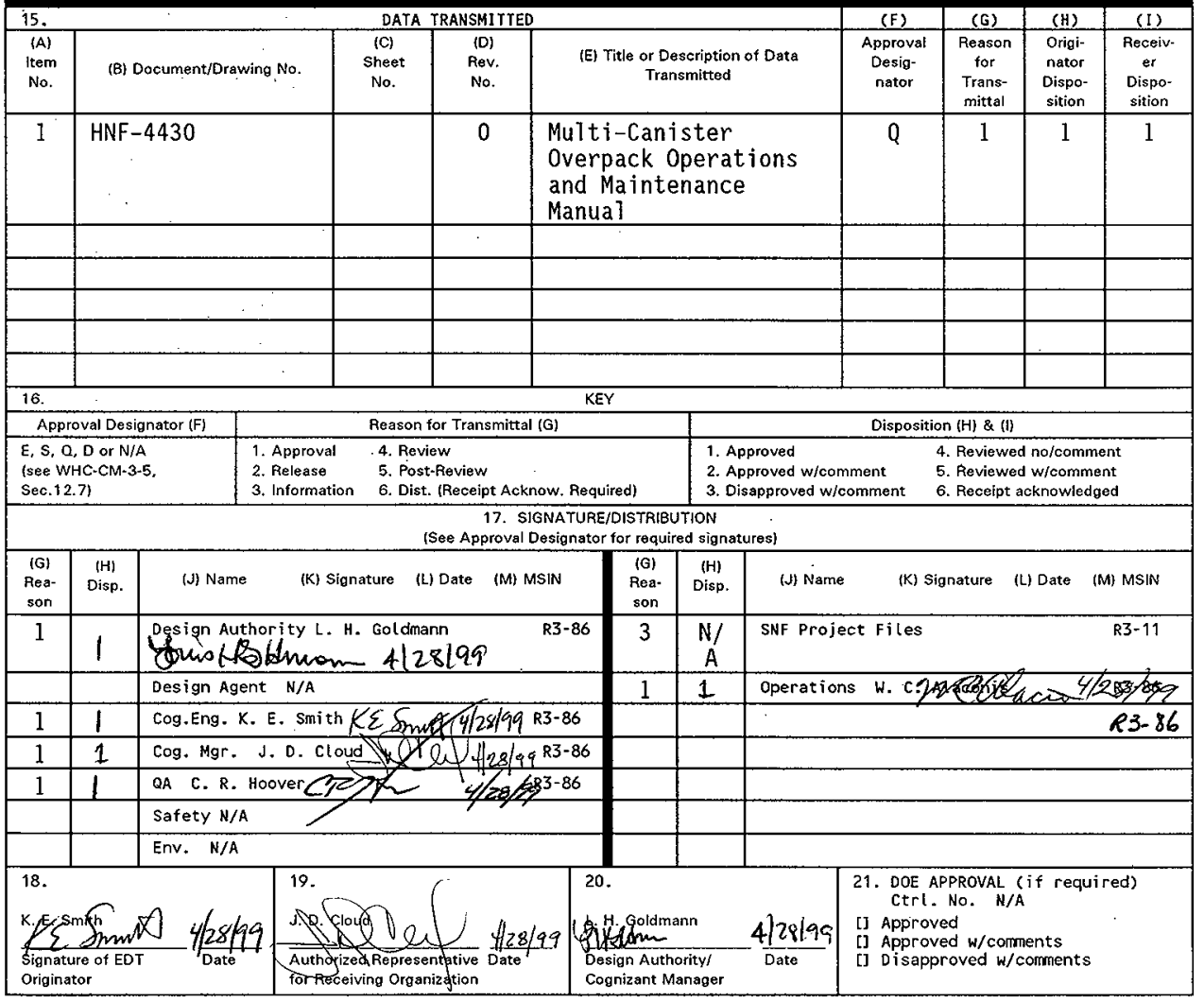

BD-7400-172-2(05/96) GEF097 


\title{
Multi-Canister Overpack Operations and Maintenance Manual
}

\section{S. R. Pierce}

ARES Corporation for DE\&S Hanford, Inc., Richland, WA 99352

U.S. Department of Energy Contract DE-AC06-96RL13200

\author{
EDT/ECN: $626813 \quad$ UC: 600 \\ Org Code: 2T340 Charge Code: 105532/AA30 \\ B\&R Code: EW7040000 Total Pages: 38
}

Key Words: MCO, Spent Fuel, Packaging, Container, Maintenance

Abstract: This manual provides general operating and maintenance instructions for the Multi-Canister Overpack. Procedure outlines included are conceptual in nature and will be modified, expanded, and refined during preparation of detailed operating procedures.

TRADEMARK DISCLAIMER. Reference herein to any specific commercial product, process, or service by trade name, trademark, manufacturer, or otherwise, does not necessarily constitute or imply its endorsement, recommendation, or favoring by the United States Government or any agency thereof or its contractors or subcontractors.

Printed in the United States of America. To obtain copies of this document, contact: Document Control Services, P.0. Box 950, Mailstop H6-08, Richland WA 99352, Phone (509) 372-2420; Fax (509) 376-4989.
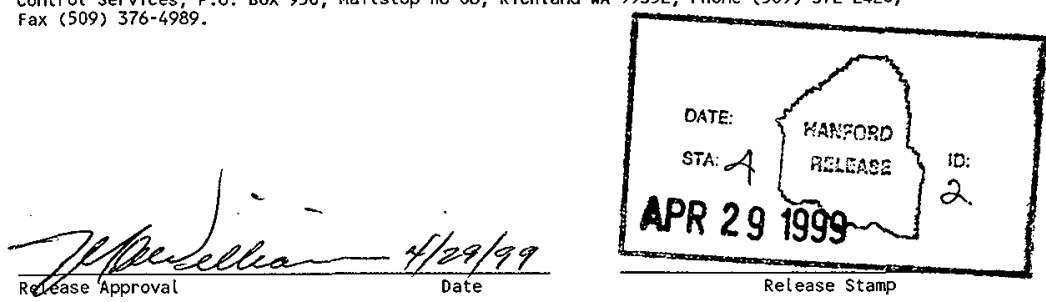

Approved for Public Release 
HNF-4430, Rev. 0

MULTI-CANISTER OVERPACK

OPERATIONS AND MAINTENANCE MANUAL

April 28, 1999 


\section{TABLE OF CONTENTS}

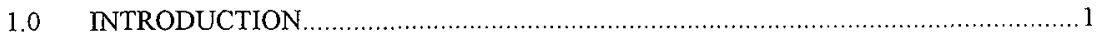

1.1 Purpose

1.2 Scope

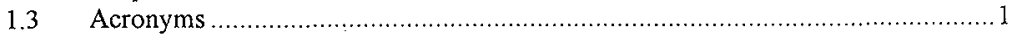

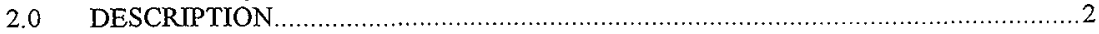

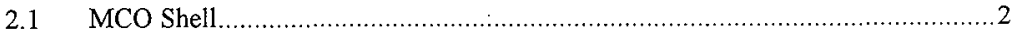

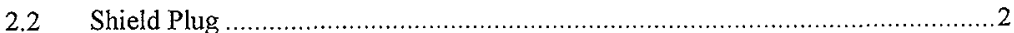

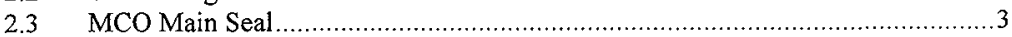

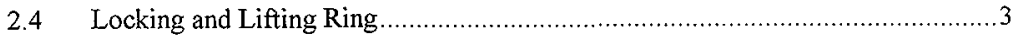

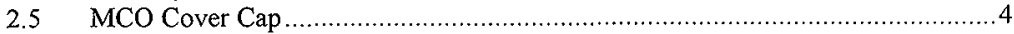

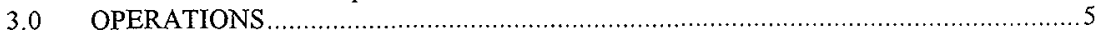

3.1 Place Empty MCO in Transport Cask ..................................................... 5

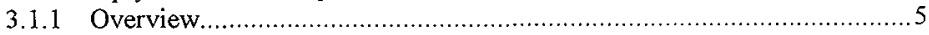

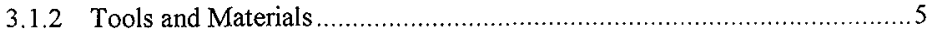

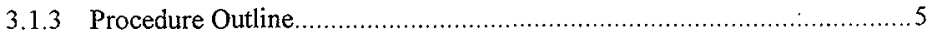

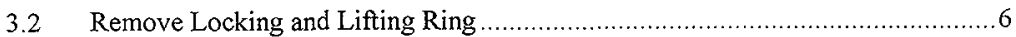

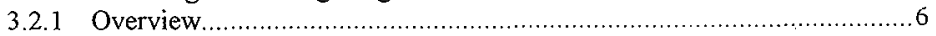

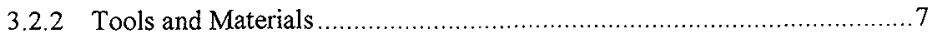

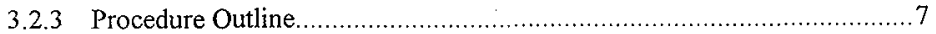

3.3 Prepare Shield Plug for Installation ......................................................... 8

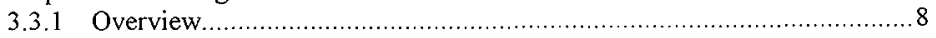

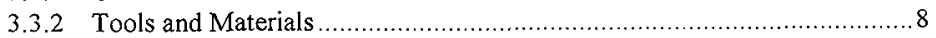

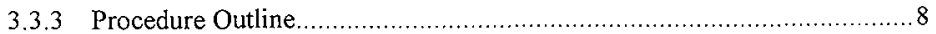

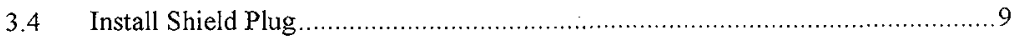

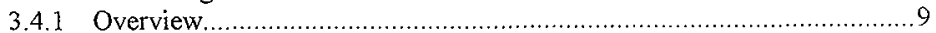

3.4.2 Tools and Materials ....................................................................... 10

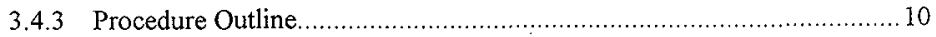

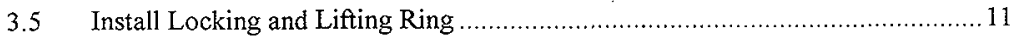

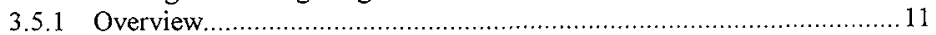

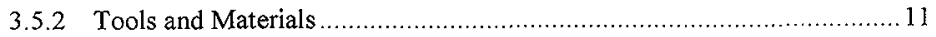

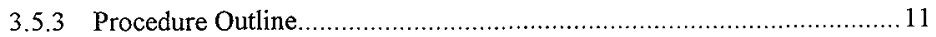

3.6 Install and Remove Process Port Cover Plates.................................................. 12

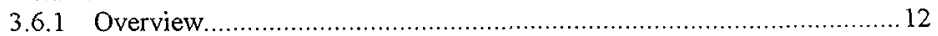

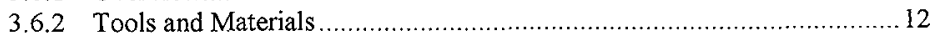

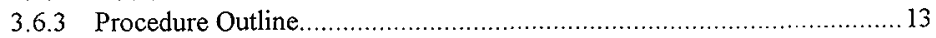

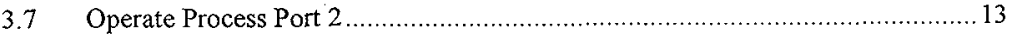

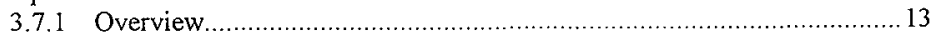

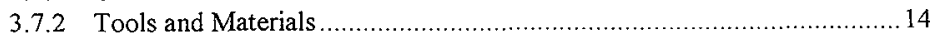

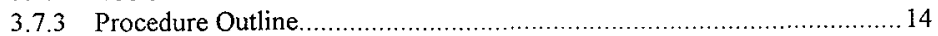

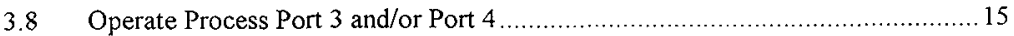

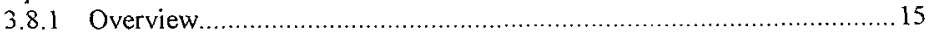

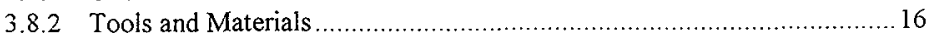

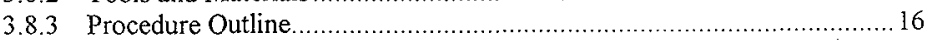




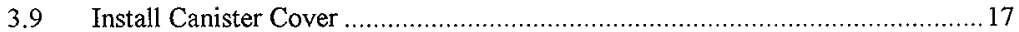

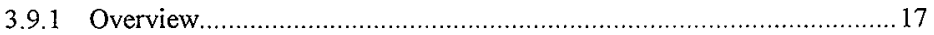

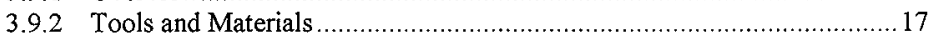

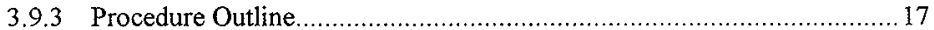

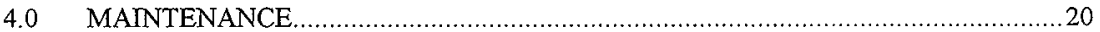

4.1 Replace Process Port Cover Plates and/or Seals ............................................20

4.2 Replace Process Valve/Plug and/or Seal...................................................2.

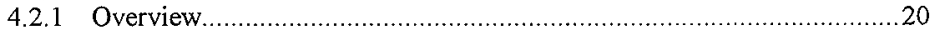

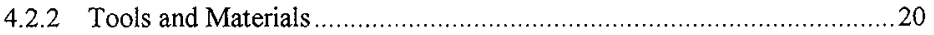

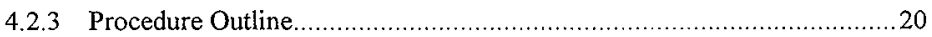

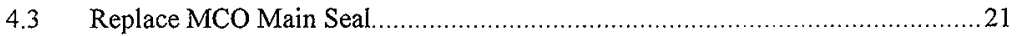

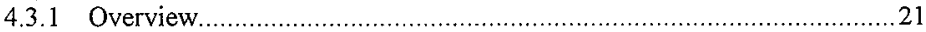

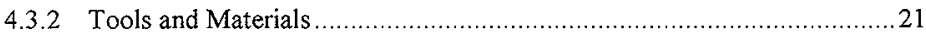

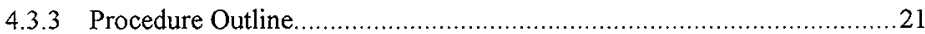

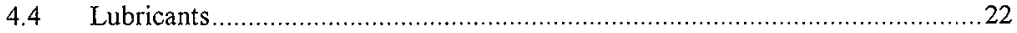

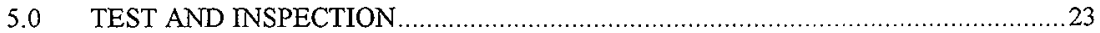

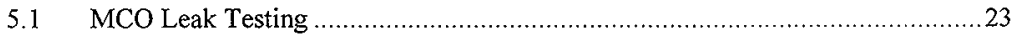

5.1.1 Mechanical Seal Leak Test at CVDF ..............................................23

5.1.2 Mechanical Seal Leak Test at CSB .................................................23

5.1.3 Final Closure Weld Leak Test ......................................................23

5.1.4 Canister Cover Test Plug Leak Test..................................................23

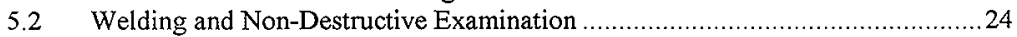

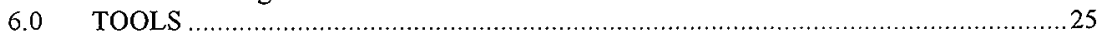

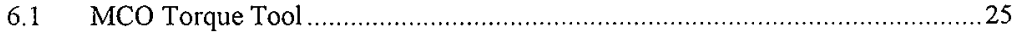

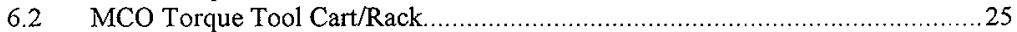

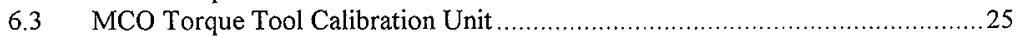

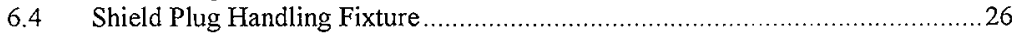

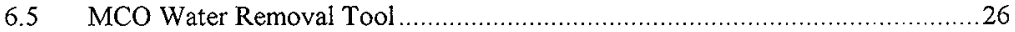

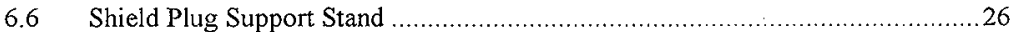

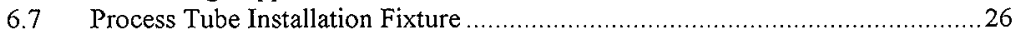

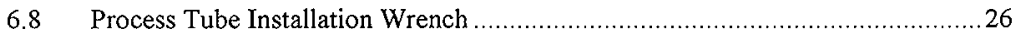

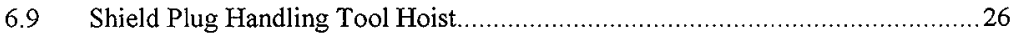

6.10 Shield Plug Installation Measuring Device ..............................................27

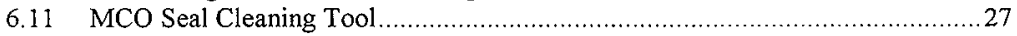

6.12 Process Tube/Shield Plug Seal Verification Equipment .................................27

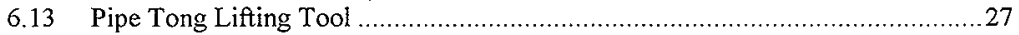

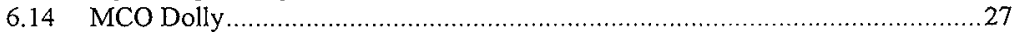

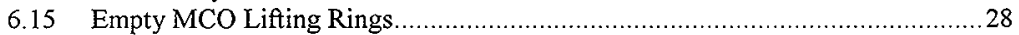

6.16 Process Port Cover Plate Installation/Removal Tool ....................................28

6.17 MCO Port Appliance Installation/Removal Tool ...........................................28

6.18 MCO Port Cover/Appliance Leak Check Equipment.......................................28

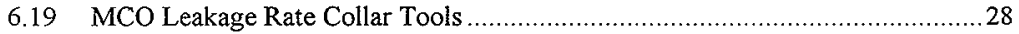

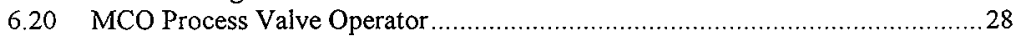

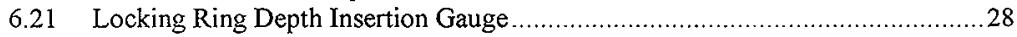

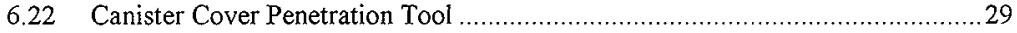


HNF-4430, Rev. 0

6.23 Canister Cover Handling and Lifting Tool

7.0 REFERENCES

\section{APPENDICES}

Appendix A Drawing List

Appendix B Materials for $\mathrm{MCO}$ and Tools 


\subsection{INTRODUCTION}

\subsection{Purpose}

This manual provides general operating and maintenance instructions for the Multi-Canister Overpack (MCO). The intent of this manual is to provide Operations and Maintenance personnel the basic information needed for preparation of detailed operation and maintenance procedures. The procedure outlines included herein are conceptual in nature and will be modified, expanded, and refined during preparation of detailed operating procedures.

\section{$1.2 \quad$ Scope}

This manual encompasses normal operating and maintenance activities specific to the MCO. The activities identified in this manual may be performed at the $\mathrm{K}$ Basins, the Cold Vacuum Drying Facility (CVDF), or the Canister Storage Building (CSB). However, specific information relating to the process operations at these facilities is not in the scope of this manual. This manual does not specifically address recovery plans for failed testing or operating activities.

The information contained in this manual is summary in nature and subject to revision. Several design and process details are still under development during initial preparation of this manual, particularly in the area of tooling. Therefore, a revision to this manual will be necessary after finalizing the details currently under development.

\subsection{Acronyms}

$\begin{array}{ll}\text { ANSI } & \text { American National Standards Institute } \\ \text { ASME } & \text { American Society of Mechanical Engineers } \\ \text { CSB } & \text { Canister Storage Building } \\ \text { CVD } & \text { Cold Vacuum Drying } \\ \text { CVDF } & \text { Cold Vacuum Drying Facility } \\ \text { HEPA } & \text { High-Efficiency Particulate Air } \\ \text { MCO } & \text { Multi-Canister Overpack } \\ \text { MHM } & \text { MCO Handling Machine } \\ \text { NDE } & \text { Non-Destructive Examination } \\ \text { QA } & \text { Quality Assurance } \\ \text { SCC } & \text { Standard Cubic Centimeters } \\ \text { SLOP } & \text { South Loadout Pit } \\ \text { UNC } & \text { Unified Coarse }\end{array}$




\subsection{DESCRIPTION}

The MCO is the storage/process vessel for stabilizing and storing the spent nuclear fuel currently stored in the Hanford K Basins. The MCO consists of the following major components: the shell, shield plug, locking and lifting ring, and canister cover. Each component has a unique identification number for tracking and accountability purposes. The shield plugs and shells are interchangeable. The fit-up between the collar and both the locking and lifting ring and the cover cap are unique. Hence, the cover caps and locking and lifting rings are matched to correspondingly marked shell assemblies. A brief description of MCO components is provided in the following sections. A detailed description of MCO components is provided in Smith (1999).

\section{$2.1 \quad$ MCO Shell}

The MCO shell (H-2-828043) is a vertical, cylindrical stainless steel container with access at the top end. After fuel basket loading, the MCO is closed with a mechanical closure assembly that consists of the shield plug, the main seal, and the locking and lifting ring. The shell is fabricated from 0.5 -in. thick plate rolled into a 24 -in. diameter cylinder. Overall length is 160 in when assembled with the mechanical closure. The MCO cavity is approximately $23 \mathrm{in}$. in diameter and 140 in. long.

\subsection{Shield Plug}

The shield plug (H-2-828045) is a cylindrical forging designed to mate with the open end of the MCO shell. The shield plug is a multifunctional component of the MCO. It provides a mechanical confinement and containment boundary until the cover cap is welded in place. It provides also for axial shielding to allow personnel access to the top of the MCO. Access to the top of the MCO is necessary for securing the mechanical closure and for drying and processing operations. The shield plug retains the MCO main seal that seals against the shield plug and the MCO collar. The top of the shield plug has four penetrations that are used for process connections to the interior of the $\mathrm{MCO}$.

- $\quad$ Port 1 is a multi-function port that will contain a pressure gauge for monitoring MCO internal pressure. It connects to a 1 -in. penetration that leads to the MCO internal HighEfficiency Particulate Air (HEPA) filter bank. The cover plate for this port has a fourbolt pattern with captivated bolts.

- Port 2 connects to 1-in. penetration that leads to the MCO internal HEPA filter bank. This port contains a threaded plug valve. The valve is a $1-7 / 8$ in. threaded plug drilled in the center and cross-drilled below the top of the threads. As the valve is unthreaded, it exposes the cross-drilled holes to allow flow. The top of the process valve has both an external hexagonal operator and an internal hex socket that interface with the valve operator. This port is primarily for vacuum process exhaust at the CVDF. This port is used to vent the interior of the MCO to the transport cask during transfer between the $\mathrm{K}$ 
Basins and the CVDF. There are two different type cover plates for this Port; a blind flange cover plate and an orifice (1-in.) cover plate. The orifice cover plate is used when the $\mathrm{MCO}$ is flooded and the blind flange cover plate is used after cold vacuum drying. Both type cover plates for this port have a four-bolt pattern with captivated bolts.

- $\quad$ Port 3 connects to a 1 -in. penetration that leads to the screened, long process tube. The long process tube leads to the bottom of the MCO cavity. This port is used primarily for bulk water removal and for addition of a helium purge during the CVD process. This port contains a threaded plug valve. The process valve is similar to that described for Port 2 . The cover plate has a five-bolt pattern to allow the operator to easily identify the port. The bolts are captivated on the cover plate.

- Port 4 connects to $2 \mathrm{~mm}$ screened chamber under the shield plug. This port contains a threaded plug with a rupture disk built into the upper portion of the plug. The rupture disk is replaceable by replacing the plug. Two different cover plates are provided for this port. One cover plate contains a 1 -in. orifice that allows pressure relief if the rupture disk ruptures. The second cover plate is blind flange type similar to the cover plates over the other process ports. After water removal and cold vacuum drying (CVD) are complete, the orifice plate is replaced with the blind flange cover plate. With the blind flange cover plate installed, this port becomes inactive and remains inactive during cover cap welding and interim storage at the CSB. The cover plates have a four-bolt pattern with captivated bolts.

\subsection{MCO Main Seal}

The primary seal for the MCO is a mechanical seal between the collar and the shield plug. The seal is manufactured by Helicoflex@ and is comprised of a high strength alloy spring covered with a 300 Series stainless steel jacket and a silver outer jacket. The seal is held in place with four stainless steel clips that are secured to the shield plug. The setscrews on locking ring compress and maintain a pre-load on the seal.

\subsection{Locking and Lifting Ring}

The locking and lifting ring (H-2-828042) is a stainless steel forging with buttress threads. The locking and lifting ring is threaded into the MCO collar after the MCO, with shield plug installed, is removed from the South Loadout Pit (SLOP). The locking ring serves two functions. 1) it provides a grapple interface for handling the $\mathrm{MCO}$, and 2) it provides support for the set screws that pre-load the MCO main seal between the shield plug and MCO collar.

The locking and lifting ring includes eighteen $1-1 / 2$ in. set screws. The setscrews are equally spaced and are threaded into the locking ring. The setscrews serve as jacking bolts to pre-load the MCO main seal. The MCO torque tool provides the torque to the setscrews. 
The locking ring includes a lifting rim that provides for handling the $\mathrm{MCO}$ when unloading the $\mathrm{MCO}$ from the transport cask and handling the MCO at the CSB. The rims of the locking and lifting ring and the cover cap are continuous around the circumference of the $\mathrm{MCO}$.

\subsection{MCO Cover Cap}

The canister cover cap (H-2-828042) is a 304L stainless steel forging that mates with the MCO collar. The canister cover is installed at one of the CSB weld stations with a full penetration weld. A helium leak test and penetrant inspections of the weld are performed.

The canister cover has a recessed, $1-3 / 4$ in. opening that allows venting the chamber created by the canister cover cap, sampling of the atmosphere below the cover, and operation of the process port appliances. The opening allows the volume below the cover to be filled with helium for the leak test of the final closure weld. A threaded plug in the opening can be removed as needed for operations and testing. The opening can be aligned over any port on the shield plug. The current plan is to align the opening over Port 2. Alignment marks are used to ensure proper alignment of the canister cover prior to welding. 
HNF-4430, Rev. 0

\subsection{OPERATIONS}

\subsection{Place Empty MCO in Transport Cask}

\subsubsection{Overview}

Empty MCOs are shipped from the manufacturer to a warehouse. The MCO Warehouse Plan provides traceability to requirements relating to $\mathrm{MCO}$ storage. The MCOs (with locking and lifting ring installed) are shipped from the warehouse to the CSB. When needed at the K Basins, the MCOs are loaded into a transport cask and transported to the K Basins. The procedure for receipt and loading an empty $\mathrm{MCO}$ into a transport cask is outlined below. A detailed description of all MCO operations at the CSB is provided in Klem (1998).

\subsubsection{Tools and Materials}

The special tools and equipment that are used to place an empty MCO into the transport cask at the CSB are identified below and described in Section 6.0.

- $\quad$ Pipe Tong Lifting Tool (Section 6.13)

- $\quad$ MCO Dolly (Section 6.14)

- $\quad$ Empty MCO Lifting Rings (Section 6.15)

- Receiving Crane at CSB Load-in/Load-out Area.

\subsubsection{Procedure Outline}

In the procedure outline below, corresponding steps from the Operation Sequence Block Flow Diagram (OSBD 1998a) are identified within brackets (e.g., [Step 3-1 1]).

\section{- Deliver New MCO to CSB}

1. Position the MCO transporter in the truck vestibule [Step 6-1].

2. Attach the pipe tong-lifting tool to the receiving crane. Open the MCO shipping crate [Step 6-2].

3. Lift the MCO with the receiving crane and pipe tong-lifting tool. Place the MCO onto the MCO dolly horizontally. Repeat for each MCO on the transporter [Step 6-3].

4. Remove the MCO transporter from the truck vestibule [Step 6.4].

5. Store the MCOs at a location (TBD) inside the CSB. 
HNF-4430, Rev. 0

\section{- $\quad$ Load Empty MCO into Transport Cask}

1. Store each empty MCO on an MCO dolly until the MCO transport cask is ready to receive an empty $\mathrm{MCO}$.

2. Prepare the transport cask to receive the empty MCO. Inspect the cask lid seal. Survey and decontaminate (if needed) the cask and transporter [Steps 2-28 through 2-30].

3. Retrieve the empty MCO lifting yoke using the receiving crane [Step 6-5].

4. Remove the plastic wrap from the MCO. Remove two setscrews from the locking and lifting ring and insert the empty MCO lift rings. Attach the lifting yoke to the empty MCO lift rings [Step 6-6].

5. Lift the empty, horizontal MCO from the MCO dolly to a vertical position with the receiving crane [Step 6-7].

6. Prepare, inspect, and insert the MCO into the transport cask [Step 2-31]

7. Disconnect the lifting yoke from the MCO [Step 2-32].

8. Remove the empty MCO lift rings and reinstall the setscrews in the locking and lifting rings.

9. Close the transport cask, connect a tractor, and remove the transporter from the truck vestibule [Steps 2-33 through 2-40].

\subsection{Remove Locking and Lifting Ring}

\subsubsection{Overview}

The MCO is transported from the CSB to the $\mathrm{K}$ Basins inside the transport cask when needed for fuel loading operations. The locking and lifting ring is installed in the MCO during this transfer. The locking and lifting ring is removed from the $\mathrm{MCO}$ after placing the cask/MCO in the immersion pail, filling the pail with water, and installing the pail lid. The locking ring must be removed before installation of the MCO fuel basket guide. The procedure for removal of the locking ring is outlined below. 


\subsubsection{Tools and Materials}

The materials and lubricants necessary to remove the locking and lifting ring are identified in Table B-1. The special tools and equipment that are used to remove the locking and lifting ring from the $\mathrm{MCO}$ at the $\mathrm{K}$ Basins are identified below and described in Section 6.0.

- $\quad$ MCO Torque Tool (Section 6.1)

- $\quad$ MCO Torque Tool Cart (Section 6.2)

- $\quad$ MCO Torque Tool Calibration Unit (Section 6.3)

- $\quad \mathrm{K}$ Basin Auxiliary Hoist.

\subsubsection{Procedure Outline}

In the procedure outline below, corresponding steps from the Operation Sequence Block Flow Diagram (DE\&S 1998) are identified within brackets (e.g., [Step 9-1])

1. Perform the pre-torque calibration check of the $\mathrm{MCO}$ torque tool before each use of the tool using a Quality Assurance (QA) approved process. When not in use, the MCO torque tool is stored in the rack on the MCO torque tool cart. The MCO torque tool calibration unit is also located on the cart [Step 7-3].

2. Remove the protective shipping cover from the top of the MCO.

3. Connect the K Basin auxiliary hoist to the swivel eye on top of the $\mathrm{MCO}$ torque tool [Step 7-4].

4. Position the MCO torque tool over the MCO and manually actuate the grapple to engage the lifting rim on the locking and lifting ring [Step 7-5].

5. Rotate the hand wheel on the MCO torque tool to unthread the locking and lifting ring from the MCO. When the threads have completely disengaged, lift the locking and lifting ring from the $\mathrm{MCO}$ with the auxiliary hoist [Step 7-6].

6. Place the locking and lifting ring on to the $\mathrm{MCO}$ torque tool cart. The $\mathrm{MCO}$ torque tool remains attached to the locking and lifting ring [Step 7-7].

7. Disconnect the auxiliary hoist from the MCO torque tool [Step 7-8].

8. Manually adjust the height of the eighteen setscrews until each screw is in contact with the support plate. 


\subsection{Prepare Shield Plug for Installation}

\subsubsection{Overview}

The shield plug assembly is inspected and assembled before installation in the MCO. The shield plug is shipped from the manufacturer to the warehouse with the process valves, rupture disk, and process port cover plates installed. Initial inspections are performed at the warehouse. When needed, the shield plug is transferred to the K Basin where the MCO main seal and the long process tube are installed. Preparation of the shield plug assembly is performed in parallel with preparation of the cask/MCO and the immersion pail. The procedure for preparation of the shield plug assembly is outlined below.

\subsubsection{Tools and Materials}

The materials, lubricants, and torque values necessary for shield plug preparations are identified in Table B-1. Leak check acceptance criteria is provided in Section 5.0. The special tools, fixtures, and equipment that are used to prepare the shield plug for installation in the $\mathrm{MCO}$ are identified below and described in Section 6.0.

- $\quad$ Shield Plug Handling Fixture (Section 6.4)

- $\quad$ Shield Plug Support Stand (Section 6.6)

- $\quad$ Process Tube Installation Fixture (Section 6.7)

- $\quad$ Process Tube Installation Wrench (Section 6.8)

- $\quad$ Shield Plug Handling Tool Hoist (Lift Rig) (Section 6.9)

- $\quad$ Process Tube/Shield Plug Verification Equipment (Section 6.12)

- $\quad$ MCO Port Appliance Installation/Removal Tool (Section 6.17)

- K Basin Auxiliary Hoist.

\subsubsection{Procedure Outline}

In the procedure outline below, corresponding steps from the Operation Sequence Block Flow Diagram (DE\&S 1998) are identified within brackets (e.g., [Step 9-1]).

1. Perform any required inspections/examinations of the shield plug at the warehouse [Steps 9-1 through 9-4].

2. Transport the shield plug to the $\mathrm{K}$ Basin. Place the shield plug in a staging location TBD [Step 9-5].

3. Transfer the process tube and MCO main seal to the K Basin. The seal and tube are transferred separately from the shield plug. Inspect for damage (certified QC inspectors).

4. Install the MCO main seal on the shield plug (see note, H-1-83772, Sh. 3). 
5. Ensure the process valve in Port 2 is approximately 3 turns from the fully closed position using the MCO port appliance installation/removal tool. This will allow gas generation during shipment to the CVDF to pressurize the cask.

6. Ensure the orifice cover plates are installed over Port 2 and Port 4.

7. Align the handling fixture with the visual markers on the shield plug to ensure proper orientation with respect to the shield plug process ports using a QA approved process. Inspect the $\mathrm{O}$-ring and bolt seal rings on the shield plug handling fixture and replace if necessary. Attach the fixture to the shield plug using the four $3 / 4$-in. 10 Unified Coarse (UNC) bolts provided with the fixture [Step 9-6].

8. Connect the lift rig to the shield plug-handling fixture and the $\mathrm{K}$ Basin auxiliary hoist [Steps 9-7 and 9-8].

9. Raise the shield plug to the mezzanine and place in the shield plug support stand [Steps 9-9 and 9-10].

10. Ensure the shield plug is oriented properly and disconnect the lift rig from the shield plug. The lift rig remains attached to the auxiliary hoist [Step 9-10].

11. Lift and position the process tube in the shield plug with the process tube installation fixture. From the mezzanine, manually install and torque the process tube in the shield plug with the process tube installation wrench [Step 9-11].

12. Inspect the shield plug assembly for cleanliness and overall condition (certified QC inspector). Perform a pressure decay leak check with the process tube/shield plug verification equipment. The connection between the long process tube and shield plug shall be capable of sealing a pressure of $30 \mathrm{psig}$ (to be refined) [Steps 9-12 and 9-13].

\subsection{Install Shield Plug}

\subsubsection{Overview}

The shield plug assembly is installed in the MCO after fuel basket loading and removal of the fuel basket guide. The shield plug is installed while the cask/MCO is in the immersion pail and submerged in the SLOP. The procedure for shield plug installation is outlined below. 


\subsubsection{Tools and Materials}

The materials, lubricants, and torque values necessary for of the shield plug are identified in Table B-1. The special tools, fixtures, and equipment that are used to install the shield plug in the MCO are identified below and described in Section 6.0.

- $\quad$ Shield Plug Handling Fixture (Section 6.4)

- $\quad$ Shield Plug Support Stand (Section 6.6)

- $\quad$ Shield Plug Handling Tool Hoist (Lift Rig) (Section 6.9)

- $\quad$ Shield Plug Installation Measuring Device (Section 6.10)

- $\quad$ MCO Seal Cleaning Tool (Section 6.11)

- $\quad$ Miscellaneous Long-Handled Tool(s)

- $\mathrm{K}$ Basin Auxiliary Hoist.

\subsubsection{Procedure Outline}

In the procedure outline below, corresponding steps from the Operation Sequence Block Flow Diagram (DE\&S 1998) are identified within brackets (e.g., [Step 9-1]).

1. Clean the shield plug sealing area with the MCO seal-cleaning tool [Step 8-9].

2. Connect the Lift Rig (and K Basin auxiliary hoist) to the shield plug [Step 9-14].

3. Remove the shield plug from the support stand and place into the top of the MCO. Use long-handled tools as necessary to guide the shield plug into the MCO [Steps 9-15 and $10-1]$.

4. Verify that the shield plug is installed correctly using the shield plug installationmeasuring device. The shield plug must be approximately $4.25 \mathrm{in}$. below the weld preparation area [Step 10-2].

5. Release the Lift Rig from the shield plug and move the auxiliary hoist away from the MCO [Step 10-3].

6. Remove the lift rig from the auxiliary hoist and survey, decontaminate (if needed), and store for future use [Step 10-4]

7. The immersion pail (with cask/MCO) is raised to the upper position in the immersion pail support structure [Steps 10-5 through 10-11].

8. Remove water and decontaminate the top of the $\mathrm{MCO}$ and the shield plug-handling fixture [Step 10-12].

9. Connect the auxiliary hoist to shield plug-handling fixture [Step 10-13]. 
10. Loosen the four bolts connecting the handling fixture to the shield plug. Remove the handling fixture from the shield plug using the auxiliary hoist [Step 10-14].

11. Return the handling fixture to staging area for reuse and disconnect the auxiliary hoist [Steps 10-15 and 10-16].

12. Remove excess water, dry, survey, and decontaminate the Shield Plug Handling Fixture [Step 10-17].

\subsection{Install Locking and Lifting Ring}

\subsubsection{Overview}

The locking and lifting ring is installed in the MCO after installing the shield plug assembly and raising the immersion pail (with cask/MCO) to the upper position in the immersion pail support structure. The procedure for locking and lifting ring installation is outlined below.

\subsubsection{Tools and Materials}

The special tools, fixtures, and equipment that are used to install the shield plug in the MCO are identified below:

\footnotetext{
- $\quad$ MCO Torque Tool (Section 6.1)

- $\quad$ MCO Torque Tool Cart (Section 6.2)

- $\quad$ MCO Torque Tool Calibration Unit (Section 6.3)

- MCO Water Removal Tool (Section 6.5)

- $\quad$ Locking Ring Depth Insertion Gauge (Section 6.21)

- K Basin Auxiliary Hoist.
}

\subsubsection{Procedure Outline}

In the procedure outline below, corresponding steps from the Operation Sequence Block Flow Diagram (DE\&S 1998) are identified within brackets (e.g., [Step 9-1]).

1. Remove excess water from MCO threads using the MCO water removal tool. Decontaminate and survey as necessary [Step 10-18].

2. Apply a thin layer of lubricant to the main threads on the MCO collar and the locking and lifting ring.

M

3. Connect the $\mathrm{K}$ Basin auxiliary hoist to the MCO torque tool. The torque tool is connected to the locking and lifting ring [Step 10-19].

4. Position the locking and lifting ring in the MCO. Rotate the hand wheel to thread the locking ring into the threads on the MCO collar [Step 10-20]. 
HNF-4430, Rev. 0

5. Actuate the hydraulic wrench array on the MCO torque tool to simultaneously apply torque to the 18 set screws. Repeat until the proper torque is achieved [Step 10-21].

6. Manually actuate the grapple to disengage the $\mathrm{MCO}$ torque tool from the lifting rim on the locking and lifting ring [Step 10-22].

7. Lift the $\mathrm{MCO}$ torque tool from the $\mathrm{MCO}$ and place in the $\mathrm{MCO}$ torque tool cart.

8. Verify the locking ring is threaded to the correct depth using the locking ring depth insertion gauge. The locking ring must be a minimum of $1 / 8$ in. below the top of the shield plug.

9. Perform a post-torque calibration check of $\mathrm{MCO}$ torque tool using the $\mathrm{MCO}$ torque tool calibration unit and a QA approved process. A post-torque calibration check is performed after every use of the torque tool. QA verification is required [Steps 10-23 and $10-24]$.

10. Disconnect the auxiliary hoist from the MCO torque tool [Step 10-25].

\subsection{Install and Remove Process Port Cover Plates}

\subsubsection{Overview}

The cover plates for the process ports on the shield plug may be installed and removed as necessary to support process operations, testing, or maintenance. The procedure for cover plate installation and removal is outlined below.

Two different cover plates are provided for Ports 2 and 4 . The first cover plate contains a 1 -in. orifice and the second cover plate is a blind flange. Prior to water removal from the $\mathrm{MCO}$, the orifice cover plates are installed. The orifice cover plates are replaced with the blind flange cover plates after cold vacuum drying. Blind flange cover plates are used for Ports 1 and 3 . The Port 3 cover plate has a 5-bolt hole pattern.

\subsubsection{Tools and Materials}

The materials, lubricants, and torque values necessary for installation and removal of process port cover plates are identified in Table B-1. Leak check acceptance criteria is provided in Section 5.0. The special tools, fixtures, and equipment that are used to install and remove cover plates are identified below and described in Section 6.0.

- $\quad$ Process Port Cover Plate Installation/Removal Tool (Section 6.16)

- Torque wrench. 
HNF-4430, Rev. 0

\subsubsection{Procedure Outline}

In the procedure outline below, corresponding steps from the Operation Sequence Block Flow Diagram (DE\&S 1998) are identified within brackets (e.g., [Step 9-1]).

\section{- $\quad$ Cover Plate Installation}

1. Inspect the process port and cover plate bolt threads (internal and external) for damage, free depth, and cleanliness. Ensure no water or other liquids are present.

2. Inspect the cover plate seal for cleanliness and damage. Replace the seal if necessary. The seal must be replaced if it has been compressed five times. The seal is a slightly oval shape that allows the seal to be "snapped" into place on the cover plate.

3. Attach the process port cover plate installation/removal tool to the cover plate.

4. Place the cover plate on the process port and remove the tool from the cover plate.

5. Torque the cover plate boits to the specified torque.

- $\quad$ Cover Plate Removal

1. Loosen the cover plate bolts until the bolts disengage from the shield plug. The cover plate captivates the bolts. Approximately $22 \mathrm{ft}-\mathrm{lb}$. of torque may be required to loosen the bolts.

2. Attach the process port cover plate installation/removal tool to the cover plate.

3. Remove the cover plate from the process port. Inspect the seal and seating surfaces.

4. Inspect the port and cover plate bolt threads (internal and external) for damage and cleanliness.

\subsection{Operate Process Port 2}

\subsubsection{Overview}

The valve in Port 2 may be operated as required to support process operations. The valve may be operated with the MCO port appliance installation/removal tool, the MCO process valve operator, or the canister cover penetration tool. The valve will be operated normally with the MCO port appliance installation/removal tool. The MCO process valve operator is used to obtain a sample from the MCO interior. The canister cover penetration tool must be used to 
operate the appliance after installation of the canister cover on the $\mathrm{MCO}$. The procedure for appliance operation is outlined below.

\subsubsection{Tools and Materials}

The materials and torque values necessary to operate the valve in Port 2 are identified in Table B-1. Leak check acceptance criteria is provided in Section 5.0. The special tools, fixtures and equipment that are used to operate the appliances are identified below and described in Section 6.0 .

- $\quad$ MCO Port Appliance Installation/Removal Tool (Section 6.17)

- $\quad$ MCO Process Valve Operator (Section 6.20)

- $\quad$ Canister Cover Penetration Tool (Section 6.22)

- Torque Wrench.

\subsubsection{Procedure Outline}

In the procedure outline below, corresponding steps from the Operation Sequence Block Flow Diagram (DE\&S 1998) are identified within brackets (e.g., [Step 9-1]).

\section{- $\quad$ Canister Cover Not Installed}

1. If installed, remove the process port cover plate according to Section 3.6.

2. Place either the MCO port appliance installation/removal tool or the MCO process valve operator on the appliance. If the $\mathrm{MCO}$ process valve operator is to be used, place the operator on the appliance and attach the operator to the cover plate sealing surface on the shield plug. Inspect the gasket on the valve operator and replace if necessary. Inspect and clean the gasket seating surfaces. Torque the bolts to the specified torque.

3. Operate the valve as necessary. Approximately $105 \mathrm{ft}-\mathrm{lb}$. of torque may be required to open the appliance. Turn the valve in the counter-clockwise direction to open and in the clockwise direction to close.

- The flow path through the valve in Port 2 begins to open at approximately $6-1 / 2$ turns from the fully closed position and is fully open at approximately 12 turns ( 1 inch of travel).

4. If mechanical seal between the valve and the shield plug has been compressed five times, replace the seal according to Section 4.2

5. Close the valve and torque to the specified torque

6. If installed, remove the MCO port appliance installation/removal tool. 
HNF-4430, Rev. 0

7. Perform a leak test of the valve if required by the operation being performed.

8. If installed, remove the MCO process valve operator.

9. Record the number of times the mechanical seal was compressed.

10. Reinstall the cover plate according to Section 3.6.

\section{- $\quad$ Canister Cover Installed}

1. Remove the test plug on the canister cover according to Section 3.9.

2. Place the canister cover penetration tool on the valve.

3. Operate the valve as necessary. Approximately $105 \mathrm{ft}-\mathrm{lb}$. of torque may be required to open the appliance. Turn the valve in the counter-clockwise direction to open and in the clockwise direction to close.

- The flow path through the valve in Port 2 begins to open at approximately $6-1 / 2$ turns from the fully closed position and is fully open at approximately 12 turns ( 1 inch of travel).

4. Close the valve and torque to the specified torque.

5. Record the number of times the mechanical seal was compressed.

6. Remove the canister cover penetration tool.

7. Perform a leak test of the valve if required by the operation being performed.

8. Reinstall the test plug in the canister cover according to Section 3.9.

\subsection{Operate Process Port 3 and/or Port 4}

\subsubsection{Overview}

The appliance (valve) in Port 3 and Port 4 may be operated as required to support process operations. Port 4 does not connect to the internal HEPA filters and therefore shall only be operated when Port 2 is plugged or out of service. The appliances in Port 3 and Port 4 cannot be operated after installation of the canister cover on the MCO. 
The appliances in Port 3 and Port 4 are normally operated with the MCO port appliance installation/removal tool. However, the appliance in Port 4 may be operated with the MCO Process Valve Operator to obtain a sample from the interior of the MCO if Port 2 is unavailable. Port 2 is the normal process sample location. The procedure for Port 3 and Port 4 appliance operation is outlined below.

\subsubsection{Tools and Materials}

The materials and torque values necessary to operate the appliances in Port 3 and Port 4 are identified in Table B-1. Leak check acceptance criteria is provided in Section 5.0. The special tools, fixtures and equipment that are used to operate the appliances are identified below and described in Section 6.0.

- $\quad$ MCO port appliance installation/removal tool (Section 6.17)

- Torque wrench.

\subsubsection{Procedure Outline}

In the procedure outline below, corresponding steps from the Operation Sequence Block Flow Diagram (DE\&S 1998) are identified within brackets (e.g., [Step 9-1]).

1. If installed, remove the process port cover plate according to Section 3.6.

2. Place either the MCO port appliance installation/removal (Port 3 or Port 4) or the MCO process valve operator (Port 4 only) on the appliance. The MCO process valve operator is used to obtain a sample from the $\mathrm{MCO}$ interior.

- If the $\mathrm{MCO}$ process valve operator is used, place the operator on the appliance and attach the operator to the cover plate sealing surface on the shield plug. Inspect the gasket on the valve operator and replace if necessary. Inspect and clean the gasket seating surfaces. Torque the bolts to the specified torque.

3. Operate the appliance as necessary. Approximately $105 \mathrm{ft}-\mathrm{lb}$. of torque may be required to open the appliance. Turn the appliance in the counter-clockwise direction to open and in the clockwise direction to close.

- The flow path through the Port 3 appliance begins to open at approximately $6-1 / 2$ turns from the fully closed position and is fully open at approximately 12 turns.

- The flow path through the Port 4 appliance begins to open at approximately six turns from the fully closed position and is fully open at approximately 12 turns.

4. If mechanical seal between the appliance and the shield plug has been compressed five times, replace the seal according to Section 4.2 . 
HNF-4430, Rev. 0

5. Close the appliance and torque to the specified torque.

6. If installed, remove the MCO port appliance installation/removal tool.

7. Perform a leak test of the appliance if required by the operation being performed

8. If installed, remove the $\mathrm{MCO}$ process valve operator.

9. Record the number of times the mechanical seal was compressed.

10. Reinstall the cover plate according to Section 3.6 if appropriate for the operation performed.

\subsection{Install Canister Cover}

\subsubsection{Overview}

The canister cover is installed on the MCO at the CSB. The MCO is transferred to the CSB inside the cask. During this transfer, the shield plug and locking and lifting ring are installed to mechanically seal the MCO. Upon arrival at the CSB, the pressure inside the cask is checked, the cask is vented, and the cask lid is removed. The MCO is removed from the cask and transferred to storage vault tubes for process validation or directly to a weld station for welding, weld inspection, and weld seal leak testing. A detailed description of all MCO operations at the CSB is provided in Klem (1998). The procedure for canister cover installation is outlined below.

\subsubsection{Tools and Materials}

The materials, lubricants, and torque values necessary for installation of the canister cover and operation of the test plug are identified in Table B-1. Leak check acceptance criteria is provided in Section 5.0. The special tools, fixtures, and equipment that are used to install the canister cover and operate the test plug are identified below and described in Section 6.0.

- $\quad$ Canister Cover Lifting and Handling Tool (Section 6.23)

- $\quad$ MCO Handling Machine (MHM).

\subsubsection{Procedure Outline}

In the procedure outline below, corresponding steps from the Operation Sequence Block Flow Diagram (OSBD 1998b) are identified within brackets (e.g., [Step 3-11]).

\section{- Install Canister Cover on MCO}

1. Inspect and clean the MCO weid surface [Step 3-11]. 
HNF-4430, Rev. 0

2. Verify acceptable gas concentrations inside the MCO.

3. Place welding fixture on canister cover using the weld station gantry crane [Step 3-12].

4. Lift the canister cover (with welding fixture) using the canister cover lifting and handling tool and the gantry crane.

5. Place the canister cover and welding fixture on the MCO [Step 3-13].

6. Inspect cap and align weld head [Step 3-14].

7. Perform first weld pass. Clean the weld and perform penetrant inspection [Steps 3-15 through 3-20].

8. Perform a mid-level pass liquid penetrant examination.

9. Complete final weld passes [Steps 3-21 through 3-27].

10. Clean the weld. Perform the leak test of the girth weld and a penetrant examination. [Steps 3-28 through 3-37].

\section{- $\quad$ Install Test Plug}

1. Inspect the test plug, seal, and test port (including threads and seating surfaces) for cleanliness and damage.

2. Fill the chamber under the cover cap with helium.

3. Check that the seal is positioned on the test plug according to Drawing No. 14119 (EG\&G Pressure Science).

4. Install test plug and new seal in the canister cover test port using a $1-1 / 4$ in. hex socket. Torque to the specified torque [Step 3-38].

5. Leak test is performed after installation of the test plug.

\section{- $\quad$ Remove Test Plug}

1. Remove the test plug using a $1-\mathrm{t} / 4$ in. hex socket. Approximately $100 \mathrm{ft}-1 \mathrm{~b}$. of torque may be required to remove the plug [Step 3-38].

2. Inspect the test plug, seal, and test port (including threads and seating surfaces) for cleanliness and damage. 
HNF-4430, Rev. 0

- Install Cover Plate on Test Plug

1. When operation of the test plug is no longer required, weld the cover plate over the plug [Steps 3-40 through 3-42].

2. Clean the weld. Perform a leak test and penetrant examination [Steps 3-43 through 3-45]. 
HNF-4430, Rev. 0

\subsection{MAINTENANCE}

\subsection{Replace Process Port Cover Plates and/or Seals}

The general procedure for replacement of a process port cover plate and/or seal is the same for each of the four process ports on the shield plug. The procedure for removal and installation of process port cover plates described in Section 3.6 should be followed when replacement of a cover plate and/or seal is required.

\subsection{Replace Process Valve/Plug and/or Seal}

\subsubsection{Overview}

The general procedure for replacement of a process valve or plug and/or seal is the same for each of the four process ports on the shield plug. The rupture disk in Port 4 is replaced by replacing the entire plug assembly. The procedure for replacement of a process valve or plug and/or seal is outlined below.

\subsubsection{Tools and Materials}

The special tools that are used to replace a process valve/plug and/or seal are identified below and described in Section 6.0 .

- $\quad$ MCO Port Appliance Installation/Removal Tool (Section 6.17)

- Torque wrench.

\subsubsection{Procedure Outline}

1. If installed, remove the process port cover plate according to Section 3.6.

2. Place the MCO port appliance installation/removal tool on the appliance (valve or plug). Turn the tool in the counter-clockwise direction and remove the appliance from the process port. The mechanical seal is captivated on the appliance and is removed with appliance. Approximately $130 \mathrm{ft}-\mathrm{lb}$. of torque may be required initially to remove the appliance.

3. Inspect the process port (including the seal seating surface and internal threads) for damage and cleanliness.

4. Remove the mechanical seal from the appliance. The seal should be replaced whenever an appliance is removed.

5. Inspect the appliance (including the seal seating surface and external threads) for cleanliness and damage. Clean or replace the appliance as necessary. 
HNF-4430, Rev. 0

6. Attach a new seal to the new or reused appliance. Verify proper seal placement according to the applicable vendor drawing identified in Table B-1.

7. Install the appliance using the MCO port appliance installation/removal tool. Torque the appliance to the specified value.

8. Perform a leak test.

9. If removed, reinstall the cover plate over the process port according to Section 3.6.

\subsection{Replace MCO Main Seal}

\subsubsection{Overview}

The MCO main seal may be compressed once and is not reused. Replacement of the main seal may be necessary if damage is noted during the assembly inspection, problems occur during installation and/or torquing of the locking ring, or if the leak test at the CVDF does not satisfy the specified acceptance criteria. The procedure for replacement of the MCO main seal is outlined below.

Replacing the MCO main seal after installation of the shield plug and locking ring is an abnormal maintenance operation. Furthermore, the facilities and equipment necessary to remove the shield plug and locking ring from the $\mathrm{MCO}$ exist only at the $\mathrm{K}$ Basins. Therefore, a recovery plan will be required if MCO main seal replacement must be performed after installation of the shield plug and locking ring.

\subsubsection{Tools and Materials}

The materials necessary for replacement of the MCO main seal are identified in Table B-1. There are no special tools required to replace the main seal prior to installing the shield plug in the $\mathrm{MCO}$.

\subsubsection{Procedure Outline}

1. Remove the four retainer clip screws and the mechanical seal from the shield plug.

2. Dispose of the seal, retainer clips, and screws appropriately. These parts are not to be reused. Inspect the seating surface on the shield plug for damage and cleanliness.

3. If the seal is being replaced because of a failed leak test, inspect the seating surface on the MCO collar for cleanliness and damage.

4. Minor defects on either seating surfaces may be touched-up using an emery cloth. Rub the emery cloth in-line with the lay of the lathe tool marks (H-2-828042, Sh. 1, Note 2). 
HNF-4430, Rev. 0

5. Attach a new seal to the shield plug with new retainer clips and screws. The screws are tightened hand-tight. Verify proper seal placement per Drawing H-2-828041 and the applicable vendor drawings identified in Table B-1.

\subsection{Lubricants}

Neolube (graphite/alcohol) is the only lubricant approved for use on MCO components. The use of lubricant on the threads of the locking and lifting ring and the MCO collar is mandatory. The use of lubricant on the port appliances, cover plate bolts, and the cover cap test plug is optional.

The Design Authority must approve all lubricant substitutions prior to use. Lubricants shall have a design temperature above $270^{\circ} \mathrm{F}$ and must not produce any off-gases above this temperature. Lubricants for use on special tools are identified in Table B-1 and the applicable design drawing. 
HNF-4430, Rev. 0

\subsection{TEST AND INSPECTION}

\subsection{MCO Leak Testing}

All leak rate testing on Hanford site shall be performed per approved procedures satisfying the requirements of ANSI N14.5 and ASME Section V, Article 10, Appendix IV. Leak test equipment is operated and maintained by properly certified non-destructive examination (NDE) contractor personnel.

\subsubsection{Mechanical Seal Leak Test at CVDF}

Leak rate testing of the MCO mechanical seal, including the MCO main seal and shield plug process valves, is performed at the CVDF. After the CVD process is completed, the MCO is pressurized with helium to approximately $7 \mathrm{psig}$. Test equipment is installed, the process ports and shield plugs are dried, and a vacuum is drawn. Any leakage passes through a helium mass spectrometer for analysis. The acceptance criteria is $1 \times 10^{-5} \mathrm{scc} / \mathrm{sec}$. The process port cover plates are on the shield plug are installed after this test.

\subsubsection{Mechanical Seal Leak Test at CSB}

Leak rate testing of the MCO mechanical seal, including the MCO main seal and shield plug process valves, is performed at the CSB after process validation sampling. An optional mechanical seal leak test may be performed for MCOs that do not undergo process validation sampling. After process validation sampling, the MCO is pressurized with helium. A test fixture is installed and a vacuum is drawn. Any leakage passes through a helium mass spectrometer for analysis. The acceptance criteria is $1 \times 10^{-5} \mathrm{scc} / \mathrm{sec}$.

\subsubsection{Final Closure Weld Leak Test}

The MCO final closure weld is leak tested with helium at the CSB. A test fixture with inflatable seals is installed over the final closure weld and the volume under the cover cap is filled with helium through the test port on the canister cover. A vacuum is drawn and any leakage through the closure weld passes through a helium mass spectrometer for analysis. The acceptance criteria is $1 \times 10^{-7} \mathrm{scc} / \mathrm{sec}$.

\subsubsection{Canister Cover Test Plug Leak Test}

The test plug on the MCO cover cap is installed after the leak test of the final closure weld. A test fixture is installed over the plug and a vacuum is drawn. Any leakage from the plug and seal passes through a helium mass spectrometer for analysis. The acceptance criteria is $1 \times 10^{-7}$ $\mathrm{scc} / \mathrm{sec}$. The cover plate is installed. 
HNF-4430, Rev. 0

\subsection{Welding and Non-Destructive Examination}

The MCO cover cap provides a welded closure that is capable of meeting the containment leakage criteria of $1 \times 10^{-7} \mathrm{scc} / \mathrm{sec}$. Welding and non-destructive examination (NDE) are performed according to ASME Code Section III, Division I, Subsection NB. The final closure weld will be qualified by use of Code Case N-595 that requires liquid penetrant inspection and leakage rate testing.

Two welds are performed on the canister cover; the final closure weld and the cover plate weld over the test plug. Both welds are performed at one of the CSB Weld Stations. The welding contractor provides the welding and NDE equipment.

The final closure weld is a full penetration weld located just below the top of the locking ring on the collar of the MCO shell. The final closure weld shall be liquid penetrant examined at the root and each $1 / 4$-in. of weld material including the cover pass. The final closure weld is not radiographically examined due to the configuration and MCO contents.

The cover plate weld on the canister cover shall be liquid penetrant inspected at the root and at approximately each $1 / 4-$ in. of weld material including the cover pass. 
HNF-4430, Rev. 0

\subsection{TOOLS}

The special tools, fixtures, and equipment supporting $\mathrm{MCO}$ operations are identified in the following sections. A brief description of each tool, a reference document/drawing, and information regarding tool operation is provided. As tool designs are completed, tested, and finalized this section of the manual will be updated as appropriate.

\subsection{MCO Torque Tool}

The MCO torque tool (Drawings H-1-83485 and H-1-83942) is used to thread the locking and lifting ring into the $\mathrm{MCO}$ collar and to torque the set screws that compress the MCO main seal. Two of these tools are provided at the K Basins ( $\mathrm{KE}$ and $\mathrm{KW}$ ). The $\mathrm{MCO}$ torque tool includes a hydraulic wrench array, hydraulic power pack, and a counterweight assembly.

The MCO torque tool is positioned over the locking and lifting ring and a manually actuated grapple attaches to the lifting rim on the locking ring. Once the locking and lifting ring is inserted into the $\mathrm{MCO}$, a hand wheel on the torque tool is rotated to thread the locking ring into the main threads on the MCO collar. Proper placement of the locking ring is verified with the locking ring depth insertion gauge. After locking ring depth is verified, the hydraulic wrenches on the MCO torque tool are actuated simultaneously. Eighteen wrenches apply the proper torque to each setscrew.

\subsection{MCO Torque Tool Cart/Rack}

The MCO torque tool cart/rack is used for storing the torque tool when the tool is not in use. The cart also provides a rack for storing the locking and lifting ring after removing the ring from the $\mathrm{MCO}$. Two carts are provided at the $\mathrm{K}$ Basins. The rack will include a plate with 1/16-in. high nubs that interface with the setscrews on the locking and lifting ring. The setscrews are manually adjusted until contact is made with each nub thus ensuring the setscrews are recessed a fixed amount from the bottom of the locking ring. This ensures the torque tool applies pressure evenly to the shield plug. The MCO torque tool calibration unit and the hydraulic power unit for the $\mathrm{MCO}$ torque tools are also mounted on the cart.

\subsection{MCO Torque Tool Calibration Unit}

The MCO torque tool calibration unit (Drawing H-1-83921) is used to verify that the MCO torque tool provides the proper torque to adequately seal the MCO. Two calibration units are provided at the $\mathrm{K}$ Basins. The calibration unit includes an array of 18 electronic torque sensors, a pressure sensor, and a data recording system. A calibration check of the MCO torque tool is performed before and after each use. 


\subsection{Shield Plug Handling Fixture}

The Shield Plug Handling Fixture (Drawing DESH-49-034a) is used to lift the shield plug. The shield plug is lifted onto the shield plug support stand and into the MCO in the SLOP (after fuel basket loading). Two handling fixtures are provided at the $\mathrm{K}$ Basins. The handling fixtures are bolted to the top of the shield plug using four, $3 / 4 \mathrm{in}$.-10 UNC bolts. An O-ring seal on the fixture and seal rings around the bolts prevent basin water from contaminating the upper surfaces of the shield plug. Sluicing and suction ports are provided on the fixture allow removal of contaminated water in the annular space between the handling fixture and the MCO collar threads. Visual markers on the shield plug-handling fixture are provided to indicate the position of the process ports on the shield plug. Observational techniques are in development.

\subsection{MCO Water Removal Tool}

To be determined.

\subsection{Shield Plug Support Stand}

The shield plug support stand (Drawing DESH-49-036) is a carbon steel fixture attached to the mezzanines in the K Basins. Two support stands are provided. The shield plug support stand supports the shield plug and limits shield plug movement during process tube installation. The mezzanine deck height of $12 \mathrm{ft} 6$ in. provides the required access to lift the $12 \mathrm{ft} 3 \mathrm{in}$. long process tube.

\subsection{Process Tube Installation Fixture}

The process tube installation fixture (Drawing DESH-49-035) is used to lift, position, and tighten the long process tube into the shield plug. The process tube installation fixture is mounted next to each shield plug support stand in the $\mathrm{K}$ Basin mezzanines. The installation fixture is a carbon steel counterweighted articulated arm that supports the process tube. The fixture allows an operator in the mezzanine to hand tighten the process tube into the shield plug.

\subsection{Process Tube Installation Wrench}

The process tube installation wrench is used to insert the process tube into the shield plug at the proper torque. The wrench includes a 1-1/8 in. crowfoot attachment and a torque wrench. Two wrenches are provided at the $\mathrm{K}$ Basins. The final torque shall be $50 \mathrm{ft}-\mathrm{lb}$. (to be refined). The wrench interfaces with the process tube at a hex connection on the tube.

\subsection{Shield Plug Handling Tool Hoist}

The shield plug handling tool hoist is a small, stainless steel, electric-operated, removable hoist that is mounted on the existing K Basin auxiliary hoist. Two hoists are provided at the K Basins. This hoist is used to prevent the $\mathrm{K} \mathrm{Basin}$ auxiliary hoist hook from getting wet as the shield plug is inserted into the MCO. The hoist has a nylon-/plastic-coated cable to allow easy 
decontamination. The cable has a centering device to prevent the shield plug from traversing back and forth as it is lowered underwater into the $\mathrm{MCO}$.

\subsection{Shield Plug Installation Measuring Device}

The shield plug installation measuring device (Drawing DESH-49-040) is to verify proper installation depth of the shield plug with respect to the threads on the MCO collar. The shield plug must be approximately 4.25 in. below the top of the MCO collar weld preparation area prior to tightening the locking ring set screws. The measuring device will be a stainless steel, longhandled depth gauge. Two measuring devices are provided at the $\mathrm{K}$ Basins. Rotational positioning of the shield plug is done using visual markers and long-handled tools.

\subsection{MCO Seal Cleaning Tool}

The MCO seal cleaning tool is used to clean the shield plug sealing area underwater before shield plug installation. The cleaning tool is comprised of a water-jet ejector, a long pipe handle (providing pressurized water to the ejector), and a plastic gliding surface contoured to fit the weld prep edge at the upper end of the MCO. Two MCO seal cleaning tools are provided at the $\mathrm{K}$ Basins. The need for this tool is currently being re-evaluated.

\subsection{Process Tube/Shield Plug Seal Verification Equipment}

The process tube/shield plug seal verification equipment is used to perform a pressure decay leak test of the connection between the shield plug and the long process tube. Two sets of equipment are provided at the $\mathrm{K}$ Basins. The seal verification equipment includes a test plug, a pressure regulator, a pressure gauge, an air relief valve, and a plug valve. Test pressure is to be determined.

\subsection{Pipe Tong Lifting Tool}

The pipe tong lifting tool is used at the CSB to load an empty MCO onto the MCO dolly. Two lifting tools are provided at the CSB. The pipe tongs are commercially available (Crescent Pipe Tongs $(B)$ and are built to withstand three times the rated load. The pipe tongs interface with the MCO shell at designated lift points to ensure the MCO is balanced during lifting.

\subsection{MCO Dolly}

The MCO dolly (Areol Company Tool Drawing \#82920) is a large four-wheeled cart used to move empty MCOs (with locking and lifting rings) at the CSB. The MCO dolly has gimbaled wheels, manually locking brakes, and a hinge plate that allows an overhead crane to lift the MCO into a vertical position. The dolly has a carrying capacity of over $3,000 \mathrm{lb}$. Four units are provided at the CSB. 


\subsection{Empty MCO Lifting Rings}

The empty MCO lifting rings are stainless steel lifting bolts used to lift the empty MCO to the vertical position and then into the transport cask. Two sets of the lifting rings are provided at the CSB. Two set screws (180 degrees apart) are temporarily removed from the locking and lifting ring and replaced with the lifting bolts. The lifting bolts are threaded to match the set screws and include a $1 / 2$ in. -13 drilled and tapped hole in the head for inserting a commercially available clevis eyebolt. The receiving crane at the CSB interfaces with the eyebolt and lifts the MCO.

\subsection{Process Port Cover Plate Installation/Removal Tool}

The process port cover plate installation/removal tool is used to install and remove the process port cover plates on the shield plug. The installation and removal tool is needed to lift the cover plates because the cover plates are flush with the surface of the shield plug. The tool is a commercially available knurled rim steel knob with a threaded steel stud that will interface with a threaded hole ( $1 / 4$ in.-20 UNC-2B) in the center of the cover plates. Seven installation and removal tools are provided in the four CVD process bays, the CSB, and the $\mathrm{K}$ Basins.

\subsection{MCO Port Appliance Installation/Removal Tool}

The MCO port appliance installation/removal tool is used to install, remove, and operate the process valves and plugs in the MCO process ports. Each appliance has a 1-5/16 in. hex head for installing and removing. The install/removal tool is a small stainless steel $\mathrm{T}$-handled wrench. One tool is provided in each of the four CVD process bays and one at each K Basin.

\subsection{MCO Port Cover/Appliance Leak Check Equipment}

To be determined.

\subsection{MCO Leakage Rate Collar Tools}

To be determined.

\subsection{MCO Process Valve Operator}

The MCO process valve operator is used to operate the valves in the shield plug process ports for sampling activities. The valve operator is a spring bolted assembly that provides sealing of the $\mathrm{MCO}$ to atmosphere and allows operation of the port valve. Three process valve operators are provided at the CSB and eight at the CVDF..

\subsection{Locking Ring Depth Insertion Gauge}

The locking ring depth insertion gauge (Drawing DESH-49-0Xl) is used to verify that the locking ring is threaded to the correct depth in relation to the shield plug. After the locking and lifting ring is installed and torqued. The ring must be a minimum of $1 / 8 \mathrm{in}$. below the top of the 
HNF-4430, Rev. 0

shield plug. The depth gauge will provide a "go, no-go" signal to the Operator. It will be a simple carbon steel gauge with a handle. Two units are provided at the $\mathrm{K}$ Basins.

\subsection{Canister Cover Penetration Tool}

The canister cover penetration tool is used to operate the valve in Port 2 after the canister cover has been installed. This tool fits through the canister cover access penetration.

\subsection{Canister Cover Handling and Lifting Tool}

The canister cover handling and lifting tool (Drawing DESH-49-0X4) is used to handle the canister cover prior to welding the cover onto the MCO collar. 


\subsection{REFERENCES}

COGEMA 1998a, MCO Main Seal Drying at CVD, COGEMA-SVLT-INS-003.4, Rev. 0 (Draft), COGEMA Engineering Corporation, Richland, Washington.

COGEMA 1998b, MCO Main Seal Leak Test at CVD, COGEMA-SVLT-INS-003 .5, Rev. 0 (Draft), COGEMA Engineering Corporation, Richland, Washington.

COGEMA 1998c, MCO Main Seal Leak Test at CSB, COGEMA-SVLT-INS-003.6, Rev. 0 (Draft), COGEMA Engineering Corporation, Richland, Washington.

DE\&S 1998, Operation Sequence Block Flow Diagram MCO Loading \& Cask Load-Out, H-183772, Rev. 0, DE\&S Hanford, Inc., Richland, Washington.

Klem 1998, Canister Storage Building Process Technical Manual, HNF-1719, Rev. D, COGEMA Engineering Corporation, Richland, Washington.

OSBD 1998a, Draft Operating Sequence Block Diagram MCO Receipt and Shipping cask Handling, H-2123400 Sheet 3, April 1998, Flour Daniel Inc., Richland, Washington.

OSBD 1998b, Draft Operating Sequence Block Diagram MHM MCO Cap Weldment, H2123400 Sheet 4, February 1998, Flour Daniel Inc., Richland, Washington.

Pajunen 1999, Cold Vacuum Drying Process Technical Mamual, HNF-SD-SNF-TM-001, Rev. 1 (Draft), COGEMA Engineering Corporation, Richland, Washington.

Praga 1998a, MCO Loading and Cask Loadout Technical Manual, HNF-2169, Rev. 0, DE\&S Hanford, Inc., Richland, Washington.

Praga 1998b, Spent Nuclear Fuel Processing Overview, HNF-SD-SNF-TM-002; Rev. 0, DE\&S Hanford, Inc., Richland, Washington.

Smith 1999, Multi-Canister Overpack Design Report, HNF-SD-SNF-DR-003, Rev. 2, DE\&S Hanford, Inc., Richland, Washington. 


\section{Appendix A}

MCO Drawing List

\begin{tabular}{|c|c|c|c|}
\hline 3.9. & 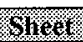 & Roxsion & 1\%. \\
\hline $\mathrm{H}-2-828040$ & & 2 & MCO Drawing List \\
\hline \multirow[t]{3}{*}{$\mathrm{H}-2-828041$} & Sh 1 & 2 & \multirow[t]{3}{*}{ MCO Assembly } \\
\hline & Sh 2 & 2 & \\
\hline & Sh 3 & 2 & \\
\hline \multirow[t]{3}{*}{$\mathrm{H}-2-828042$} & Sh 1 & 2 & \multirow[t]{3}{*}{ MCO Closure } \\
\hline & Sh 2 & 2 & \\
\hline & Sh 3 & 2 & \\
\hline $\mathrm{H}-2-828043$ & & 2 & MCO Shell \\
\hline $\mathrm{H}-2-828044$ & & 2 & MCO Shell Bottom \\
\hline \multirow[t]{3}{*}{$\mathrm{H}-2-828045$} & Sh 1 & 2 & \multirow[t]{3}{*}{ MCO Mechanical Closure Shield Plug } \\
\hline & Sh 2 & 2 & \\
\hline & Sh 3 & 2 & \\
\hline $\mathrm{H}-2-828046$ & & 2 & MCO Internal Filter Guide \\
\hline H-2-828047 & & 2 & MCO Process Valves \\
\hline $\mathrm{H}-2-828048$ & & 2 & MCO Process Port Cover Plates \\
\hline $\mathrm{H}-2-828049$ & & 2 & MCO Internal Filter Assembly \\
\hline $\mathrm{H}-2-828050$ & & 2 & MCO Basket Stabilizer Extension \\
\hline $\mathrm{H}-2-828051$ & & 2 & MCO Process Tube \\
\hline $\mathrm{H}-2-828052$ & & 2 & MCO Process Tube Guide Cone \\
\hline H-2-828053 & . & 2 & MCO Basket Support Plate \\
\hline \multirow[t]{5}{*}{ H-2-828060 } & Sh 1 & 2 & \multirow[t]{5}{*}{ K-Basin SNF Storage Basket Mark IA } \\
\hline & Sh 2 & 2 & \\
\hline & Sh 3 & 2 & \\
\hline & Sh 4 & 2 & \\
\hline & $\mathrm{Sh} 5$ & 2 & \\
\hline \multirow[t]{5}{*}{$\mathrm{H}-2-828065$} & Sh 1 & 3 & \multirow[t]{5}{*}{ K-Basin SNF Scrap Basket Mark IA } \\
\hline & Sh 2 & 3 & \\
\hline & Sh 3 & 3 & \\
\hline & Sh 4 & 3 & \\
\hline & Sh 5 & 3 & \\
\hline \multirow[t]{4}{*}{$\mathrm{H}-2-828070$} & Sh 1 & 1 & \multirow[t]{4}{*}{ MCO Mark IV Storage Basket } \\
\hline & Sh 2 & 1 & \\
\hline & Sh 3 & 1 & \\
\hline & $\mathrm{Sh} 4$ & 0 & \\
\hline \multirow[t]{4}{*}{$\mathrm{H}-2-828075$} & Sh 1 & 3 & \multirow[t]{4}{*}{ MCO Mark IV Scrap Basket } \\
\hline & Sh 2 & 3 & \\
\hline & Sh 3 & 2 & \\
\hline & Sh 4 & 0 & \\
\hline
\end{tabular}


HNF-4430, Rev. 0

Appendix B

Materials for MCO and Tools

B-1 


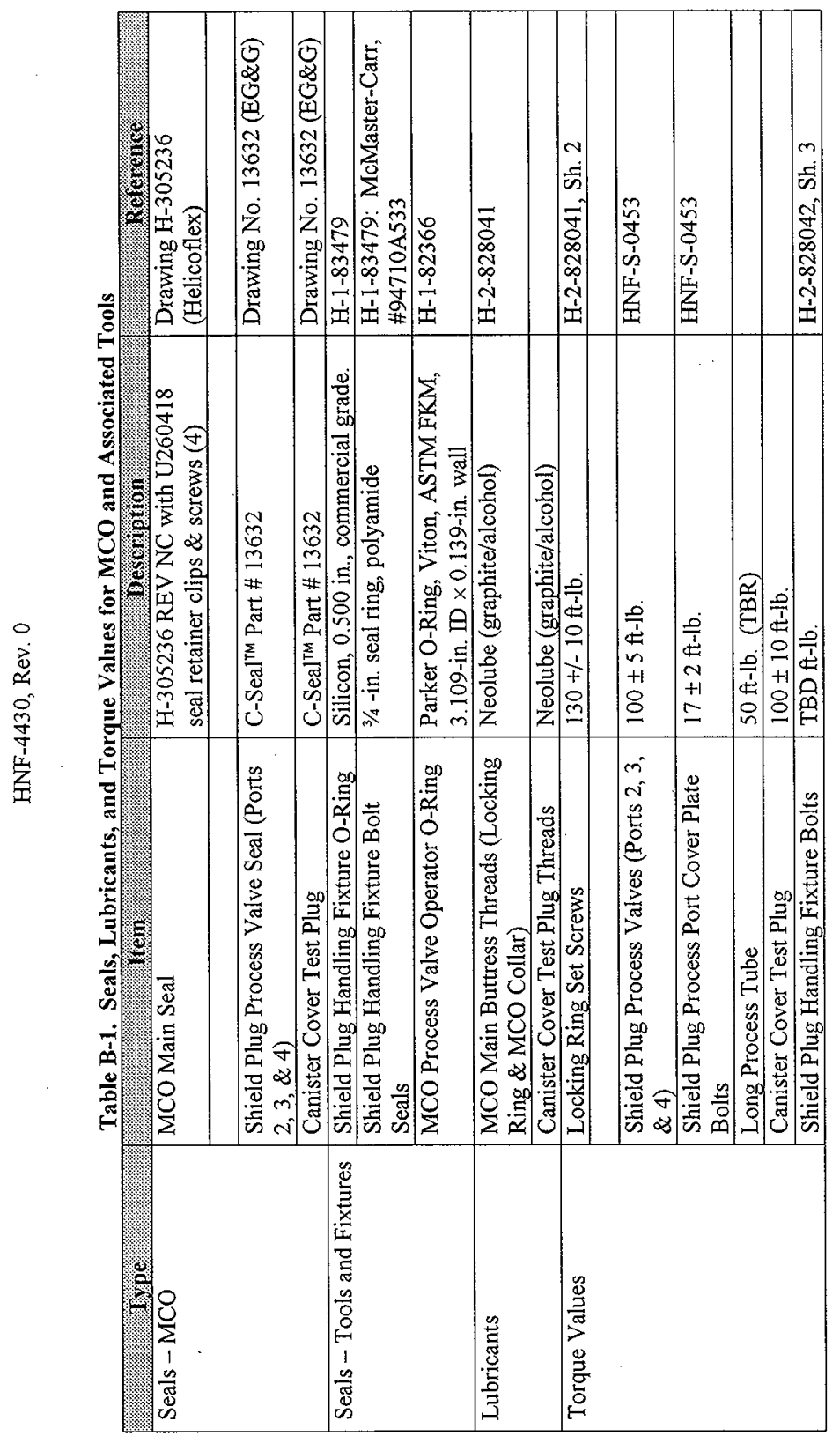

